\title{
Investigation of a UK Financial Organisation's Green Computing Strategy
}

\author{
Joseph Thackray, Lesley Earle, Ah-Lian Kor, Colin Pattinson \\ School of Computing, Creative Technologies, and Engineering \\ Leeds Beckett University, Leeds, UK
}

\begin{abstract}
This study involves an investigation on the Green ICT strategy of a financial organization. The baseline for the Green ICT strategy implementation is elicited via a semi-structured interview and assessed using a bespoke tool developed for a SURF Maturity Model driven framework. This framework encompasses Green ICT strategy, Greening of ICT in the organization and Greening of operations in ICT. The results of the study reveal that the overall baseline score is 1.8 out of 5.0 which is a relatively low score. However, the overall target level set for organization is 3.0 out of 5.0 accompanied by a roadmap and action plan (with several key action objectives) that covers a 5-year timeframe to bridge the gap between the baseline and the target. An IT representation from the organization provides some feedback on the action plan that leads to several amendments relating to cloud technology and a written business case for promoting a Green ICT strategy.
\end{abstract}

\section{Introduction}

ICT-related energy use is comparable to that of the aviation industry (UK Parliamentary Office of Science and Technology (2008). ICT's substantial energy consumption has a significant impact on GHG emissions and climate change where $2 \%$ of global carbon emissions come from manufacturing and using of Information and Communication Technology (ICT). In Europe, ICT equipment and services account for about $8 \%$ of EU's electricity consumption and $2 \%$ carbon emissions. According to the Smart 2020 report by the Global e-Sustainability Initiative, GeSI (2008), the ICT sector's emissions are expected to increase, from 0.53 billion tonnes (Gt) carbon dioxide equivalent (CO2e) in 2002 to 1.43 GtCO2e in 2020 (in Business As Usual, BAU, scenario). Based on the Smarter 2020 report, the forecast is revised down to $1.27 \mathrm{GtCO} 2 \mathrm{e}$, representing $2.3 \%$ of the global emissions (note: these figures are based on actual energy efficiencies realized from 2008-2012 as well as on updated data). Identified ICT as an enabler across the global economy (e.g. Smart Manufacturing, Smart Agriculture, Smart Buildings, Smart Grid, etc.) in Smarter2020 and Smarter 2030 could help effect a total reduction of $12 \mathrm{GtCO} 2 \mathrm{e}$ global emissions by the year 2030. According to OECD (see Reimsbach-
Kounatze [13]), government (and business) green ICT strategies typically cover the following areas: stimulate Green ICT R\&D and innovation; increase Green ICT diffusion and ICT applications; promote environmental-related ICT skills and awareness; optimising ICT value chains. Currently, clear and measureable policies, and initiatives are necessary to enhance the environmental improvement of ICTs and to deploy ICT across the global economy to address global warming and environmental degradation (ibid).

\section{Organisation and sector background}

The case study is on one of the largest financial organisations in the UK and has a global presence in the finance and services industry. In recent years, the sector has experienced several instabilities with the recession in 2007 and more recently Brexit in 2016 causing uncertainty in financial markets with many economists predicting a significant and rapid effect on the UK economy (BBC News, 2017). There has been a rise in inflation and devaluation of the pound since the vote (ibid). These factors are set to have a negative impact on the organisation from a financial standpoint. More positively the rise in investment in technology has had a positive influence on the sector. ICT Technology is set to replace many workflow processes (Business Insider UK, 2016). This means an increase in use of ICT in the workplace and therefore an increase in influence for Greening of ICT in the workplace.

\subsection{Definition of Green ICT strategy}

Green ICT strategy is defined as the first steps taken to reduce overall carbon footprint (The Royal Borough of Kensington and Chelsea, 2008). It comprises a written strategy, an action plan for the strategy, an implementation plan for the strategy and finally evaluation of the strategy success. The UK Green ICT Strategy (UK Government, 2011) supports the Greening Government ICT vision - "A cost effective and energy efficient ICT estate, which is fully exploited, with reduced environmental impacts to enable new and sustainable ways of working for the public sector". The strategy describes how ICT will contribute to greening the UK government commitments, economic benefits 
and reduced environmental impact. The strategy sets out the government's green ICT commitments and action plan in the form of a roadmap. The step by step procedures are depicted in Figure 5.

\subsection{Rationale}

Why choose this organisation? This organisation has been chosen as it is a large organisation in the financial sector. This is relevant as the organisation has influence on the UK economy and from a social perspective. But more importantly, it has influence on the industry from a green perspective. A completed and implemented green ICT strategy for this organisation would provide guidelines and relevance for other organisations in the financial sector and so could therefore be used more widely. The organisation will also contribute a substantial proportion towards the carbon emissions for the sector. So, the combine effect of reducing its own carbon emissions and providing guidelines for others in the sector is good reason for choosing it.

\subsection{Why conduct this study?}

Relevance to climate change: Climate change is a growing concern for the global community as discussed in the background section of the report. The organisation is included in this community and must contribute to the overall reduction in global carbon emissions and push towards a sustainable planet.

Organisational reputation: The organisation's reputation is a consideration for the rationale for the report. In modern days, it is considered good to be green and green initiatives are increasing in popularity [6]. If an organisation is found to not be striving to be green, the public response may have a detrimental effect on the organisation. In the financial sector, reputation is a key feature to the success of large organisations.

Cost savings and Sustainability: The biggest value in going green is the contribution to maintaining the health of the environment [6]. Utilising sustainability methods can prevent waste of natural and operational resources which contributes to both sustainability and cost savings for the organisation. An organisation will value its assets and any potential savings that can be made or contributions towards sustainability. A big example of what could be included in these savings is waste reduction for the organisation (ibid). This study will help to identify potential cost savings and sustainability considerations for the organisation.

Corporate and social responsibility: Organisations have an ethical and social responsibility to look after both their community and its environment. Therefore, one of the key drivers for the study is to help the organisation to achieve this through being green in its ICT strategy.

\subsection{Aim and objectives}

This report will have the following aim and objectives for the study of the organisation's ICT strategies:

Aim: To understand the ICT strategy of a given financial organisation and how the strategy is implemented, provide a roadmap and action plan on how this strategy can be better improved or implemented to enhance the Green ICT strategy for the organisation.

\subsection{Objectives}

A list of research objectives to support the aim is as follows:

- R01 - To conduct a critical literature review on the current trends in Green ICT strategy from EU down to the sector of the given organisation to understand the background of the study.

- R02 - To examine current macro level methodologies in Green ICT strategies to provide a structure for the methodology to be used to look at the ICT strategy of the organisation.

- R03 - To survey current techniques in micro methodology and outline the techniques and tools to be used for the study.

- R04 - To conduct a semi-structured interview and document review to acquire data on the company's current Green ICT strategy and their future strategy.

- R05 - To conduct data analysis for R04 to establish the baseline for the organisation.

- R06 - To assess the awareness of end users on Green ICT directives and legislation, the Green ICT strategy of the organisation and how the users behave to adhere to the legislation and Green ICT strategy.

- R07 - To devise a roadmap with target and action plan for the organisation's Green ICT strategy.

- R08 - To provide future strategy for implementation of green IT strategy of the organisation and highlight any key changes or developments in current process, gaining their feedback on the action plan and roadmap.

\section{Literature Review}

Pattinson and Kor (nd) have discussed the definition of Green IT. Many terms have been used synonymously with 'Green IT'. They are 'Green Computing', 'Green ICT', 'Sustainable Computing', 'Sustainable IT', 'Environmental Sustainable IT', 'Environmental-friendly IT or Computing', etc. Some definitions are very strategy-focused. A 
narrow definition of Green IT refers to strategies for reducing energy consumption and the environmental impact of products, equipment, services and systems. On the other hand, a broader definition of Green IT encompasses strategies address environmental and social issues (e.g. BCS, 2012), government policies, and also considering innovative as well as ecologically responsible ways for the exploitation of computing resources. Bittencourt Dolci et al. [5] state that Green IT has an important role in transforming the status quo of an organization through an integration of available resources, sustainable as well as economic policies in order to generate benefits for the environment and businesses. This is resonated by Khan et al. [11] who 'takes into account the triple bottom line' (economics, environmental, and social) and efficient use of technology which aligned to initiatives outlines in SMARTER2030).

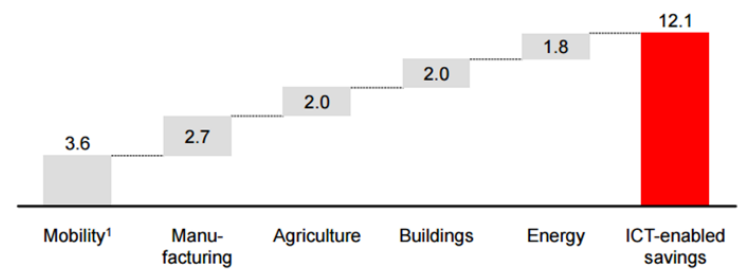

Figure 1. C02 abatement potential by sector (2030)

(GeSI, accenturestrategy, UNFCCC, 2015)

To implement Green ICT effectively in an organisation, it is essential to first understand what a Green ICT strategy encompasses in order to provide context and background information for this study to help the target organisation improve its Green ICT strategy.

The review will consider the various levels of green ICT strategy from the European level down to organisational level (in a funnel shape). Since 2008, the Global e-Sustainability Initiative has been looking at ways to reduce the overall global $\mathrm{CO}_{2}$ emissions and move towards a more sustainable society (GeSI, accenturestrategy, UNFCCC, 2015). This is a study with potential results that could be in place by 2030 . It has been recently found that ICT is becoming faster, cheaper and more accessible globally. This can have a powerful effect on environmental, economic and social change (as discussed in SMARTER 2030). To reiterate, deployment of ICT as an enabler could bring about a $20 \%$ reduction in global $\mathrm{CO}_{2}$ emissions by 2030 . Figure 1 shows the significance of ICT as a $\mathrm{CO}_{2}$ emissions abatement potential.

This is coupled with avoiding the trade-off of prosperity for environmental protection which until recently was thought to not be possible. It was also found that ICT emissions will fall from $2.3 \%$ of global emissions to just $1.97 \%$ (GeSI, accenturestrategy, UNFCCC, 2015). ICT can also offer significant environmental benefits in addition to reducing carbon emissions in other areas. For example, producing a $30 \%$ increase in agricultural crop yields saving 300 trillion tons of water and 25 billion barrels of oil per year. According to the SMARTER2030 report, 8 economic sectors will benefit most with the deployment of ICT as an enabler. They are: smart health, e-learning, smart building, smart agriculture, smart mobility, smart energy, work and business (note: the research target organisation subsumes this category), and smart manufacturing. It is estimated that a global generation of $\$ 11$ trillion in economic benefits due to ICT by 2030 as the worldwide digital economy continues to grow. ICT will connect with 2.5 billion extra people by 2030 in the developing world and provide an extra 1.5 billion with access to healthcare benefits (ibid). Figure 2 shows the financial benefits of SMARTER 2030. These two key themes, greening of ICT and greening by ICT which are highlighted in SMARTER 2030 are a key consideration for the development of the organisation's ICT strategy and will be used in the study. SMARTER 2030 also highlights three key stakeholders in the consideration of green ICT strategy including government, business leaders and consumers (ibid). The UK Green ICT Strategy will be relevant for this research target organisation because it is a UK based financial organisation.

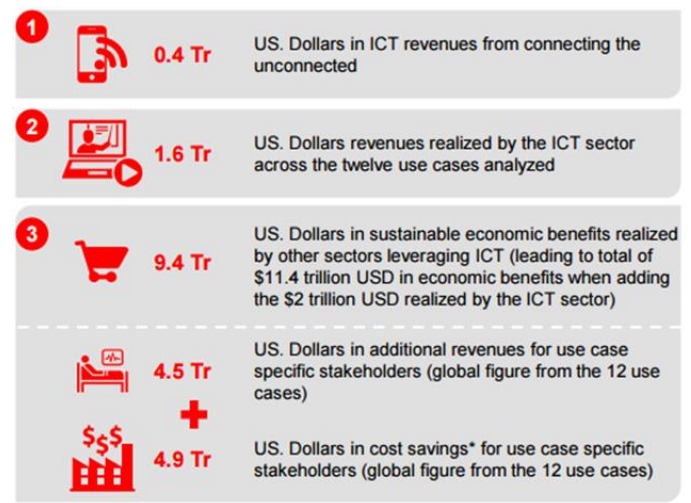

Figure 2. Economic - Global economic benefits of ICT-enabled solutions (GeSI, accenturestrategy, UNFCCC, 2015)

\subsection{UK Green ICT Strategy}

The UK Greening government document outlines the vision the government has for the UK which is a cost effective and energy efficient ICT estate enabling a sustainable public sector (HM Government, 2011). The strategy from 2011 was targeted to be implemented by 2015 . It is an approach to embed sustainable development in the procurement and operation of all central government 
departments and related organisations (ibid). On an organisational level, it targets to ensure:

- Purchase of sustainable and efficient products and services;

- Proactive management and reduction of $\mathrm{CO} 2$ emissions by $25 \%$ across government estates;

- Ensure redundant ICT is reused within government or wider public sector when practical.

The strategy states that environmental impacts of ICT spans from design all the way to disposal, through the lifecycle. It is not constrained to energy used in operations. The strategy is split into two main sections part 1 - greening by ICT across the lifecycle and part 2- using ICT as an enabler (ibid).

\subsection{Part 1 - Greening by ICT}

The strategy includes efficient operation of ICT equipment by sharing applications, infrastructure, and services such as human resources and commercial functions which are relevant for the organisation. There are propositions for a single ICT infrastructure to deliver savings and green improvements. This is happening by way of the PSN (Public Service Network). Other considerations in the strategy include pieces on Data centres, end user device strategies and sub strategies in different areas (HM Government, 2011). These factors help to improve the efficiency of the equipment and reduce carbon emissions thus greening of ICT.

\subsection{Part 2 - Using ICT as an enabler}

Similar to SMARTER 2030, the strategy considers the use of ICT as an enabler to reduce carbon emissions in other areas. Areas such as travel emissions can be reduced due to using remote communication techniques like video conferencing (e.g. see Shaw, Kor, and Pattinson [12]).

\subsection{Organisational level strategy - SURF Green ICT Maturity Model}

We have discussed a national level of Green ICT strategy. Next, it is necessary to consider the green ICT strategy at the organisational level. There are many environmental tools for organisations (e.g. Environmental Responsibility Assessment Tool (Bazarhanova, Kor, and Pattinson, 2016 and the SURF Maturity Model (SURF, 2014). Hankel and Lago (2016) have demonstrate how the SURF Maturity Model could be employed to improve their Green ICT activities.

\begin{tabular}{|l|l|l|}
\hline $\begin{array}{l}\text { Green ICT in the } \\
\text { organization }\end{array}$ & Greening of ICT & $\begin{array}{l}\text { Greening of } \\
\text { operations with ICT }\end{array}$ \\
\hline Green ICT Strategy & $\begin{array}{l}\text { Computing } \\
\text { Infrastructure }\end{array}$ & $\begin{array}{l}\text { Travel Reductions with } \\
\text { ICT }\end{array}$ \\
\hline ICT Governance & Network Infrastructure & $\begin{array}{l}\text { Space Reductions with } \\
\text { ICT }\end{array}$ \\
\hline $\begin{array}{l}\text { Green ICT } \\
\text { Procurement }\end{array}$ & Storage Infrastructure & $\begin{array}{l}\text { Energy Reductions } \\
\text { with ICT }\end{array}$ \\
\hline E-waste policy & Housing & $\begin{array}{l}\text { Paper Reductions with } \\
\text { ICT }\end{array}$ \\
\hline $\begin{array}{l}\text { Green ICT } \\
\text { Architecture Principles }\end{array}$ & $\begin{array}{l}\text { End User ICT } \\
\text { Equipment }\end{array}$ & $\begin{array}{l}\text { Other Reductions with } \\
\text { ICT }\end{array}$ \\
\hline $\begin{array}{l}\text { Information } \\
\text { Management }\end{array}$ & ICT Services & $\begin{array}{l}\text { Environmental } \\
\text { Awareness and } \\
\text { Decision Support }\end{array}$ \\
\hline $\begin{array}{l}\text { Community } \\
\text { Collaboration }\end{array}$ & $\begin{array}{l}\text { Green Software } \\
\text { Development }\end{array}$ & \\
\hline $\begin{array}{l}\text { Green ICT Supply } \\
\text { Chain Management }\end{array}$ & & \\
\hline
\end{tabular}

Figure 3. The domains and attributes of the SURF Green ICT Maturity Model - (Albert Hankel, 2014)

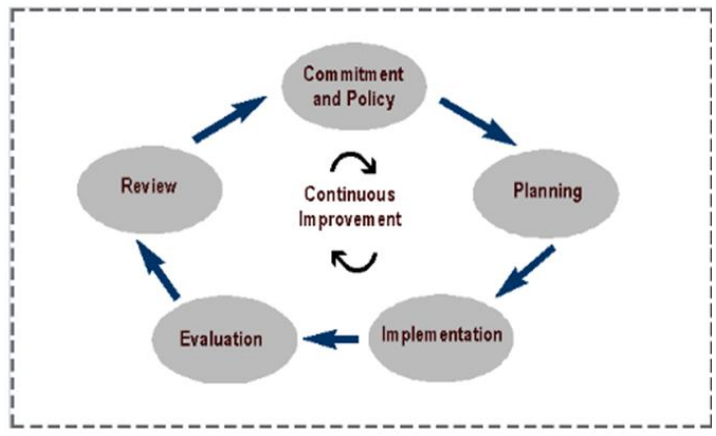

Figure 4. The continuous improvement cycle -

(United States Environmental Protection Agency

(EPA), 2017)

The SURF Maturity model is used to provide a framework for analysis of the ICT strategy of an organisation and it facilitates a quick way to obtain insights into the role of ICT for greening an organisation. This tool maps out four areas of study, Greening ICT in the organisation, greening of ICT, greening of operations by ICT and greening of primary process by ICT. This model considers the entire process for the ICT strategy of the organisation which is more comprehensive than the UK government strategy which only covers the operational level of the strategy (HM Government, 2011). It provides a structure in the form of a grid and produces spider diagram outputs to evaluate the baseline strategy and action plan for an organisation. The table below shows the areas that the SURF Maturity Model covers.

\subsection{Organisational level strategy Environmental Management Systems}

An environmental management system is a structure that allows organisations to manage their environmental goals through consistent review, evaluation and improvement of the environmental performance (United States Environmental Protection Agency (EPA), 2017). Assessing 
regulatory demands in a cost efficient and systematic way. Helping to reduce risk of non-compliance and improve the health and safety of employees. It also looks at energy conservation and improvements to the operational control of the organisation.

Diagram to show the continuous cycle of an EMS (United States Environmental Protection Agency (EPA), 2017) is found in Figure 4. The start of this process being the organisation committing to a policy or process. The combination of these two analysis methods for organisations could be used to develop a hybrid method discussed in the methodology section of the report.

\section{Methodology}

\subsection{Macro Methodology}

The existing strategies discussed above can be used as a framework to produce the methodology (see Figure 5) that is implemented in this research. For this methodology, a bespoke checklist of tools and strategies relevant to the organisation is created to help the organisation in assess and implement its Green ICT strategy. This methodology encompasses all appropriate phases of the process best depicted in Figure 5.

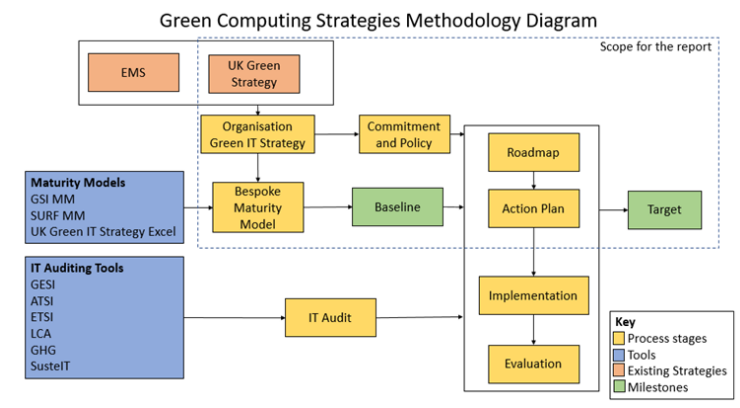

Figure 5. Green Computing Strategies

4.1.1 Scope. Before implementing the methodology, the research scope is determined.

- The scope of the study focuses on the strategy for one regional UK site owned by the organisation as looking at the entire organisation will not be practical within the time frame of study;

- The scope considers the analysis of the current strategy for the organisation or baseline;

- The scope sets the target for the organisation in consultation with relevant staff members;

- The action plan for the organisation at this stage will not consider the implementation of the strategy or further analysis;

- The strategy entails the development of a roadmap for the strategy looking at targets within a 5-year window from the time of study (April 2017);
- Use of a bespoke tool for analysis of the organisation is aligned the framework provided by the SURF Maturity Model;

- Awareness of Green ICT strategy and legislations is considered within the scope;

- The scope of the strategy addresses the "cradle to grave" areas of the lifecycle with procurement, operations and disposal all considered in the strategy piece.

4.1.2 Establish the baseline (what the organisation is currently doing). Firstly, assessment of the current organisational strategy is conducted by using the bespoke strategy tool in the SURF Maturity model and also inputs from other areas to generate a comprehensive assessment tool that is most appropriate for the organisation. Information on the organisation is gathered via interview with a member of the relevant ICT team who will remain anonymous. A document review of the organisations strategy is conducted to complement results found in the interview. The results are depicted in the form of spider diagrams shown in Section5.

4.1.3 Target. Analysis of the baseline strategy will allow the development of a target strategy for the organisation within the scope of the analysis.

4.1.4 Roadmap. Upon completion of the assessment using the bespoke assessment tool, a roadmap for improvement of the current strategy will be written based on similar practises to the UK Green IT Strategy and other relevant areas to provide a best practice strategy for the organisation. This roadmap will align the baseline strategy to the target strategy. The full strategy will be broken down into a set of objectives including immediate wins, short term, medium term and long-term objectives for the organisation to improve its strategy. Relevant literature review provides justification for the points considered in the recommended roadmap (see subsection 5.7).

4.1.5 Action plan. Upon completion of the roadmap, an action plan is devised to lay out the actions required to execute the objectives outlined in the roadmap and to provide guidance for the implementation of the new Green ICT strategy.

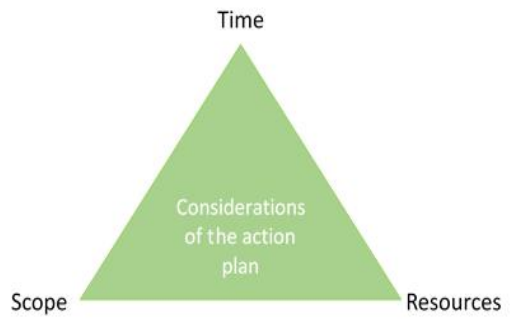

Figure 6. Considerations for the revised action plan 
Key considerations for the roadmap and the action plan are given in the form triangle diagram below (see Figure 6).

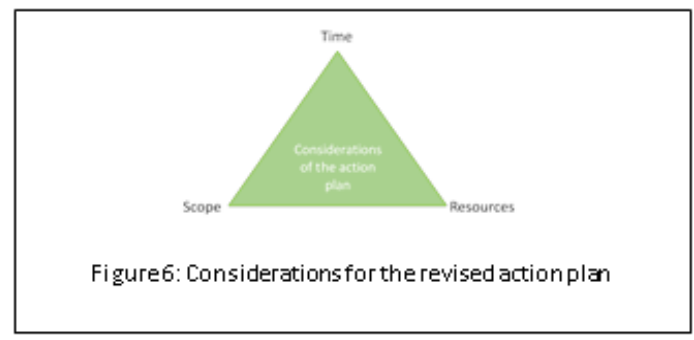

4.1.6 Feedback on revised action plan. Once the action plan is devised, feedback on the changes are collated through: interview of the significant member of organisation staff and assessment tool findings. The implementation of the strategy is beyond the scope of this research and the responsibility for its implementation will lie with the organisation's champion of Green ICT strategy.

4.1.7 Implementation. The action plan will provide a guide for the way the strategy will be implemented and how to evaluate the success of the strategy (reiterate: this is not part of the analysis for this report). Considerations for the implementation will be within the limits of the bespoke tool further considerations are out of scope for the study.

4.1.8 Evaluation. Evaluation can be conducted periodically at certain milestones after implementation through conducted ICT audits on the organisation. This will be coupled with a revisit to the bespoke tool used to initially assess the organisation. A life cycle assessment audit and use of the SUSTE-IT tool ${ }^{1}$ will provide information on the company's progress in terms of carbon emissions improvement. The reuse of the bespoke tool will provide information on how well the strategy has been implemented and how this has cascaded through the different levels within the organisation. The ICT strategy of the organisation is a fluid ongoing process and this is the justification for periodic evaluations to effect continuous improvement.

\subsection{Micro Methodology}

Details of the specific approaches (including the bespoke tool employed) in this study are discussed in the subsequent sections.

4.2.1 Bespoke assessment tool. A bespoke assessment tool is used to assess the Green ICT strategy of the organisation during this study. The tool is developed using the SURF Maturity Model as a framework (SURF, 2014). The tool focuses on
Green ICT in the organisation. This is followed by how the organisation promotes Greening of ICT and implements Greening by ICT. The tool grades the organisation between 1 and 5 with each ascending level showing the organisation's greater commitment (and action) in the context of Green ICT strategy. The output of this is a spider diagram that represents the overall score for the organisation in terms of Green ICT strategy, Greening of ICT and Greening by ICT (see Section 5).

4.2.2 Qualitative research methodology interview. Alongside the bespoke tool, a qualitative interview is conducted with an anonymous representative of the organisation who an expert in the ICT strategy is. The interview covers key green ICT strategy points such as the awareness of Green ICT strategy within the organisation, compliance with legislation and the structure of the Green ICT strategy.

\section{Results of the Study and Discussion}

Upon completion of the study, the results of the bespoke tool and interview are discussed to understand the baseline strategy of the organisation. The interview answers and results from analysed data (collected via the bespoke tool) are provided by a representative from the organisation.

\subsection{Green ICT Strategy}

The baseline Green ICT Strategy is first considered for the organisation. It is found from the interview that no strategy exists specifically for Green ICT in the organisation. See excerpt (IC1 below).

"So, I do not believe the ICT department itself has any Green Strategy. Procurement, I believe have a Green Strategy. Which is part of their sustainability piece which they do." (IC1)

The overall grading for the Green ICT strategy is given in Figure 7.

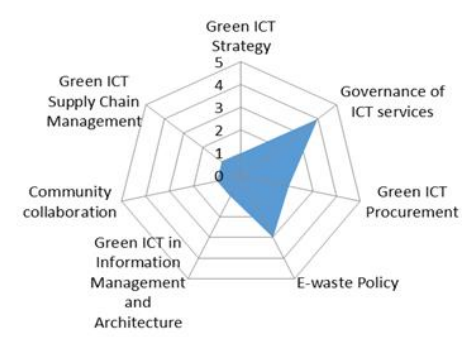

Figure 7. Spider diagram shows the organisation's Green ICT strategy - baseline

\footnotetext{
${ }^{1}$ http://www.susteit.org.uk/files/
} 
Despite this lack of Green ICT strategy, there are other areas of focus for the organisation's strategy which complement a Green ICT strategy. Firstly, the organisation's procurement (as mentioned in the comments above) does have some considerations relating to sustainability. It scored a 2 in the analysis tool and this means that some basic environmental considerations are made. This is supported by comments in the interview (see interview excerpt IC2). However, considerations are not made for hardware (see interview excerpt IC3 in response to a query concerning the organisation's green procurement policy).

"We have made purchases, within the ICT department that would green issues in mind but that has not been at the forefront and it is not been a key strategy piece... This point also goes further to support the idea that the organisation's strategy complements green issues but doesn't look at them directly." (IC2)

"So for hardware I would say no, I don't think we do. We look at the performance of the hardware is and the value of the hardware." (IC3).

The focus of the ICT department is more on the performance of the equipment and the cost of the equipment during procurement and evidence of this is found in interview excerpt IC4.

"We don't look at how its environmental impacts when that's been manufactured. Whether change is still compliant or anything like that." (IC4)

This suggests that the focus is not on Green ICT issues for the procurement of ICT. Another key area of interest is the organisation's e-waste policy. The organisation does comply with the WEEE legislation when disposing of its e-waste and this is supported by comments in IC5. The organisation also scores higher in this field with a 3 overall implying that the ICT department has a clear policy for the disposal of e-waste.

"So yes to the EU ROHS, and the WEEE legislation, we dispose of all of our waste in accordance with WEEE." (IC5)

However, compliance to WEEE legislations is due to security and data protection reasons rather than for Green ICT strategy and comments in IC6 affirm this.

"That's actually driven more around security aspect of it. We have to comply with ISO 27001 for the disposal of systems. The companies that we use are WEEE or EU rosh companies. So, they are not guided through the emissions of it they are guided through security and compliance issues." (IC6)

The organisation does score highly (see Figure 7) in terms of governance of ICT services. The representative also suggests that the organisation complies well with several legislations again for various reasons, rather than that of the Green ICT strategy and these can be seen in IC7 and IC8.
"So yes, to the EU ROHS, and the WEEE legislation." (IC7) "We have to comply with ISO 27001 for the disposal of systems" (IC8) - when asked about certain legislations the organisation complies with.

However, when asked in more detail, the representative mentioned that standards such as the ISO standards are not directly adhered to but for specific examples such as the one given below in IC9.

"So we don't directly, and the ISO standards I am aware of are 15001 and 14001. When we work with our own data centres again the things we look for are whether they were compliant or follow those prototypes or standards and whether the things we do follow those standards." (IC9)

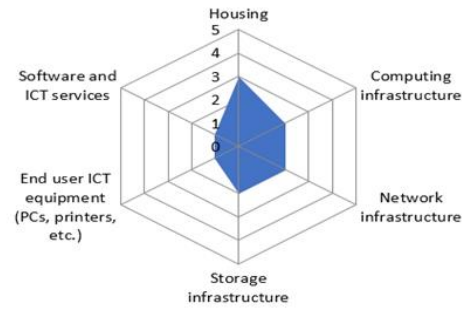

Figure 8. Spider diagram shows the Greening of ICT in the organisation - baseline

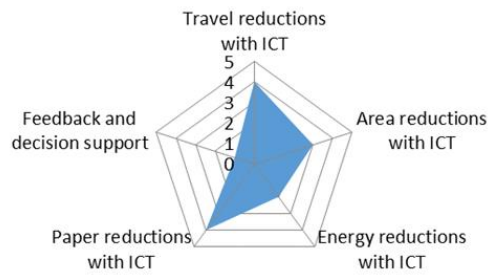

Figure 9. Spider diagram shows the Greening by ICT in the organisation - baseline

\subsection{Greening of ICT in the organisation}

The organisation also scored poorly with regards to Greening of ICT in the organisation suggesting that focus is away from the Green ICT strategy and is more aligned to other areas. The spider diagram in Figure 8 shows low scores for End User of ICT Equipment and Software with only Housing scoring as high as 3. This means that generally, there is a lack of drive in to decrease energy consumption in the ICT equipment for the organisation.

\subsection{Greening by ICT in the organisation}

In contrast, the organisation scores highly in the Greening by ICT section. Paper reduction and travel reduction both score 4 . This implies that the ICT department is actively attempting to carry out energy reduction in these areas. However, despite the high scores, these are being achieved due to the 
company's flexible working scheme. Thus, the priority is in the interest of cost reduction, and improvement of process efficiency rather than reduction due to Green ICT reasons.

\subsection{Awareness and behaviour of staff}

Finally, organisation staff's awareness and Green ICT related behaviours assessed. During the interview, the representative states that end users are only aware of the disposal procedure for ICT equipment as represented in IC10 comments.

"So I think they are only aware of the disposal of the things. I think it's acceptable because we have a controlled process for how we dispose of items." (IC10) - in response to a question on whether staff members are aware of Green ICT legislation and standards.

In terms of staff behaviours, the organisation takes Green ICT considerations as low priority and therefore, staff behaviours will reflect this. This can be seen from the representative comments in IC11. However, it can be seen that the organisation has awareness of the benefits a change in policy has and the savings that could be made.

"I think it is yes. It's a shame in a way because a leader in procurement one of his ideas was we could advertise it internally and sell it almost. Especially the Green issue because we would be saving so much energy. In a lot, more efficient places or ways of cooling things like this." (IC11)

The comments in IC12 reflect the attitude of the organisation with regards to prioritising Green ICT. It illustrates the issues and barriers caused by this that will be faced when attempting to change policies. A meaningful change in attitude and awareness will be required to enhance the Green ICT strategy for the organisation.

"You are ultimately at the whim of the business as well sometimes because the business is concerned with ticking a certain box. You know, there is nothing you can really do about that so that's just going to win all the time." (IC12)

\subsection{Summary}

In summary, it has been noted that the organisation does not have a written or official Green ICT strategy in place.

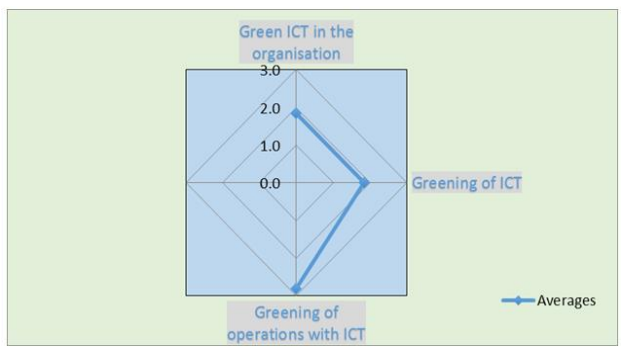

Figure 10. Average scores for the organisation baseline
However, the organisation follows several processes and policies related to other strategic areas which complement the Green ICT strategy. A strategy needs to be built around this initial starting block. The average scores for the organisation are shown in Figure 10.

The organisation averages, 1.9 for Green ICT strategy, 1.8 for Greening of ICT and 2.8 for Greening of operations within ICT (see Table 1). This gives an overall score of 2.1 out of 5 for the organisation.

Table 1. Average scores for the organisation baseline

\begin{tabular}{|l|c|}
\hline Dimensions of the strategy & Averages (between 1 - 5) \\
\hline Green ICT in the organisation & 1.9 \\
\hline Greening of ICT & 1.8 \\
\hline Greening of operations with ICT & 2.8 \\
\hline
\end{tabular}

In terms of Greening of ICT, the organisation has very low priority and improvement is necessary due to the lack of a Green ICT element in the overall strategy. For Greening by ICT, the organisation performs better for reason that are not directly related to sustainability (to reiterate: reasons due to cost reduction and process efficiency). The attitude and awareness of the organisation towards Green ICT policy needs to be significantly changed for the organisation to move forward with a Green ICT strategy. Baseline results in preceding sections reveal that there is much room for improvement in the organisation's action plan which will developed (see Tables 3 and 4).

\subsection{Action Plan for the organisation}

Having established the starting point with the baseline strategy, next, it is appropriate to develop an action plan with time frames for the organisation to move towards building and improving on its Green ICT strategy. The results from the bespoke tool and the interview are considered for the development of the action plan. This will be done in three key stages:

- Establishing a target point for the organisation to reach for its Green ICT strategy;

- Develop a roadmap of steps and time frames to reach this target;

- Devise an action plan for the key actions required to reach the target. 


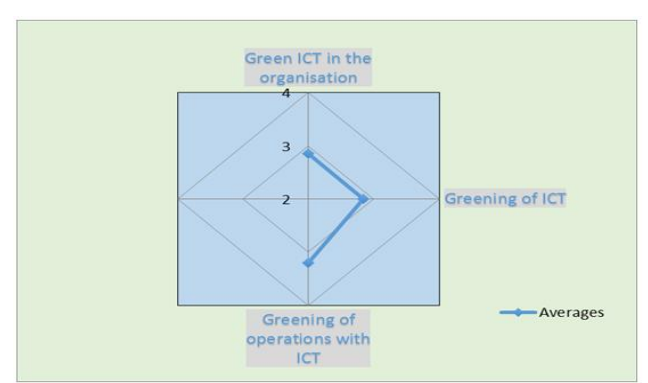

Figure 11. Average scores for the organisation target

\subsection{Target for the organisation}

The target for the organisation is broken into several points with the overall target in order to increase the overall average score in the bespoke tool from 2.1 up to 3 out of 5 . The focus of the target will be on the Green ICT strategy section and the Greening of ICT section due to the lower scores in these sections. The target overall is depicted in Figure 11.

The new average target scores for each section for the organisation are given in Table 2.

Table 2. Average scores for the organisation - target

\begin{tabular}{|l|c|}
\hline Sections of the strategy & Averages (between 1 - 5) \\
\hline Green ICT in the organisation & 2.8 \\
\hline Greening of ICT & 2.8 \\
\hline Greening of operations with ICT & 3.2 \\
\hline
\end{tabular}

The target will involve the scripting of a new Green ICT strategy for the organisation as a written and official currently does not exist. This will encompass the development of green

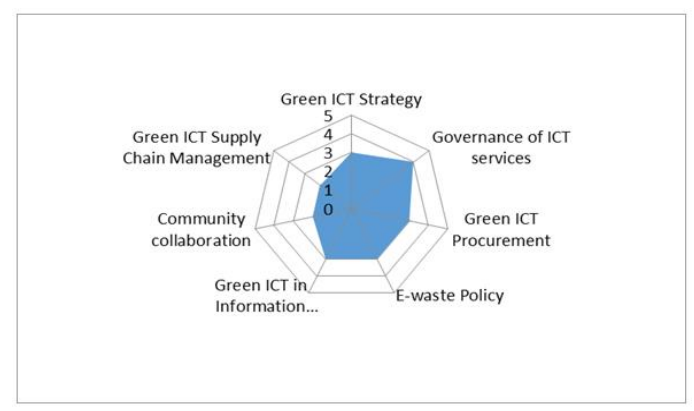

Figure 12. Spider diagram to show the Green ICT strategy for the organisation - target

ICT perspectives is several key areas such as procurement, external collaboration with suppliers, outside stakeholders, supply chain policies, et. A written Green ICT strategy which will be implemented by the organisation would drive the overall score up to 2.8 for the first section and the target spider diagram is shown in Figure 12.

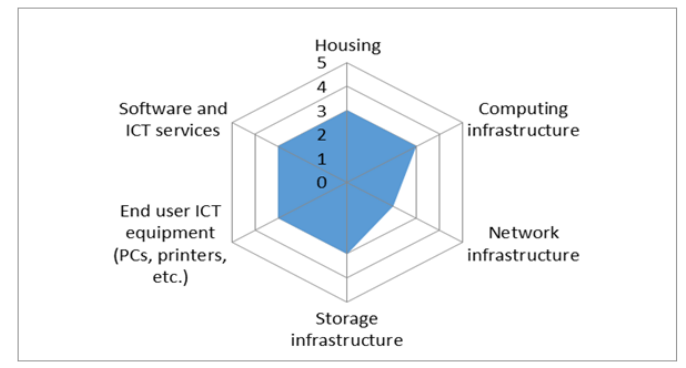

Figure 13. Spider diagram to show the Greening of ICT in the organisation - target

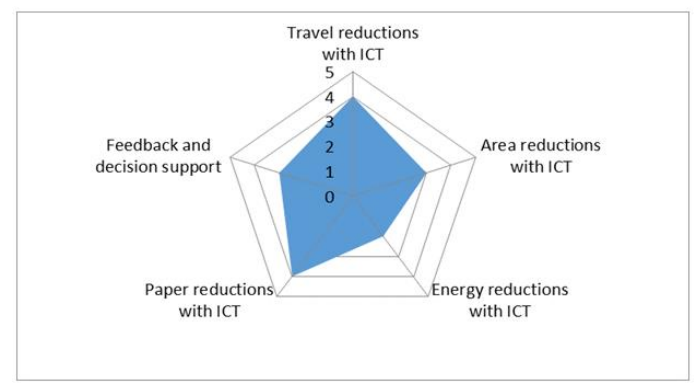

Figure 14. Spider diagram to show the Greening by ICT in the organisation - target

The target would consider the increase of the average score for Greening of ICT in the organisation (i.e. up to 2.8). This would be achieved by improving the overall resourcing and energy efficiency considerations for all types of ICT equipment and would be a key point in the overall Green ICT strategy. A target improvement such as this would yield the spider diagram in Figure 13.

Greening of operations with ICT would receive specific improvements in the areas where it scores lower (particularly, Feedback and decision support), and this will be included in the new Green ICT strategy. This will drive the average score up to 3.2 for this section. Figure 14 shows the target for this area. Finally, the target must also appropriately address the awareness and behaviour of staff. Campaigns to increase awareness of Green ICT issues and convince influential stakeholders to help improve the Green ICT strategy of the organisation must be included in the target for the organisation.

\subsection{Roadmap and Action Plan}

The roadmap will bridge the gap between the baseline and target strategy for the organisation. This will be split into several key objectives with timeframes for completion by the organisation. These will include:

- Quick wins that can be carried out in the first 3 months upon completion of the study; 
- Short term objectives for the organisation which will be carried out in the first 6-12 months upon completion of the study;

- Medium term objectives to be carried out by the first 1-2 years upon completion of the study;

- Long term objectives to be carried out in the first 5 years of the implementation of the strategy.

This means implementation of the roadmap will look to reach the target for the organisation by May 2022 (report date: May 2017). Table 3 shows full details of the roadmap and necessary actions.

Table 3. Roadmap and Action Plan for the Organisation

\begin{tabular}{|c|c|c|c|}
\hline \multicolumn{4}{|c|}{ Roadmap \& Action plan for the organisation } \\
\hline $\begin{array}{l}\text { Objective } \\
\text { No. }\end{array}$ & $\begin{array}{l}\text { Objective } \\
\text { type }\end{array}$ & Objective Description & $\begin{array}{l}\text { Completion } \\
\text { Date }\end{array}$ \\
\hline 1 & $\begin{array}{l}\text { Overall - } \\
\text { Short } \\
\text { term }\end{array}$ & $\begin{array}{llr}\begin{array}{l}\text { Develop a } \\
\text { Strategy } \\
\text { organisation }\end{array} & \begin{array}{l}\text { Green } \\
\text { for }\end{array} & \begin{array}{r}\text { ICT } \\
\text { the }\end{array} \\
\end{array}$ & May 2018 \\
\hline 1.1 & $\begin{array}{l}\text { Quick } \\
\text { Win }\end{array}$ & $\begin{array}{l}\text { Development of framework } \\
\text { of an overall Green ICT } \\
\text { strategy for the organisation } \\
\text { taking into consideration } \\
\text { current successes and areas } \\
\text { for improvement within the } \\
\text { organisation with regards to } \\
\text { Green ICT strategy. This } \\
\text { would include alignment of } \\
\text { current processes that are } \\
\text { considered "Green" but are } \\
\text { carried out for separate } \\
\text { motives into the Green ICT } \\
\text { strategy }\end{array}$ & August 2017 \\
\hline 1.2 & Short term & 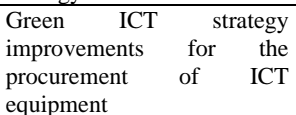 & $\begin{array}{l}\text { October } \\
2017\end{array}$ \\
\hline 1.3 & Short term & $\begin{array}{l}\text { Green ICT strategy } \\
\text { improvements for the system } \\
\begin{array}{l}\text { architecture of the } \\
\text { organisation }\end{array}\end{array}$ & $\begin{array}{l}\text { October } \\
2017\end{array}$ \\
\hline 1.4 & Short term & $\begin{array}{l}\text { Green ICT strategy } \\
\text { improvements for the } \\
\text { interactions with suppliers } \\
\text { and outside stakeholders for } \\
\text { the organisation }\end{array}$ & $\begin{array}{l}\text { October } \\
2017\end{array}$ \\
\hline 1.5 & Short term & $\begin{array}{l}\text { Roll out of full new Green } \\
\text { ICT strategy for the } \\
\text { organisation }\end{array}$ & May 2018 \\
\hline 1.6 & Short term & $\begin{array}{l}\text { Integration of Green ICT } \\
\text { strategy within overall ICT } \\
\text { strategy for the organisation }\end{array}$ & May 2018 \\
\hline 2 & $\begin{array}{l}\text { Overall - } \\
\text { Long } \\
\text { term }\end{array}$ & 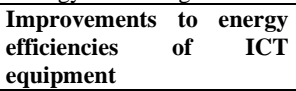 & $\begin{array}{l}\text { August } \\
2020\end{array}$ \\
\hline 2.1 & Short term & 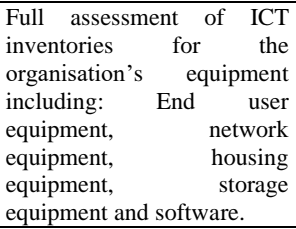 & May 2018 \\
\hline 2.2 & $\begin{array}{l}\text { Medium } \\
\text { term }\end{array}$ & $\begin{array}{l}\text { Procurement of required } \\
\text { new ICT equipment for the } \\
\text { improvement of energy } \\
\text { efficiencies based on the } \\
\text { inventory assessment } 2.1 . \\
\text { Use of new strategy for } \\
\text { procurement in } 1.1 \text { during } \\
\text { this process. }\end{array}$ & May 2019 \\
\hline 2.3 & Long term & $\begin{array}{l}\text { Roll out of assessed Green } \\
\text { ICT equipment that has been } \\
\text { procured in } 2.2 \text {. }\end{array}$ & May 2020 \\
\hline
\end{tabular}

\begin{tabular}{|c|c|c|c|}
\hline 2.4 & Long term & $\begin{array}{l}\text { Disposal of old ICT } \\
\text { equipment and e-waste } \\
\text { because of the roll out } 2.3 \text {. } \\
\text { Disposal in compliance with } \\
\text { the new Green ICT strategy } \\
1 .\end{array}$ & August 2020 \\
\hline 3 & $\begin{array}{l}\text { Overall - } \\
\text { Long } \\
\text { term }\end{array}$ & $\begin{array}{l}\text { Improvement to overall } \\
\text { awareness and behaviours } \\
\text { of staff in the organisation }\end{array}$ & $\begin{array}{l}\text { May 2022 } \\
\text { (Ongoing) }\end{array}$ \\
\hline 3.1 & $\begin{array}{l}\text { Quick } \\
\text { Win }\end{array}$ & $\begin{array}{l}\text { Presentation on the key } \\
\text { benefits of a Green ICT } \\
\text { strategy and the findings of } \\
\text { this study to raise awareness } \\
\text { of key stakeholders and } \\
\text { leaders within the } \\
\text { organisation. }\end{array}$ & August 2017 \\
\hline 3.2 & $\begin{array}{l}\text { Short term } \\
\text { (Ongoing) }\end{array}$ & $\begin{array}{l}\text { Awareness campaign on } \\
\text { Green ICT strategy and the } \\
\text { effects of ICT on the } \\
\text { environment within the } \\
\text { organisation. Ensure } \\
\text { campaign is maintained. }\end{array}$ & $\begin{array}{l}\text { May } 2018 \\
\text { (Ongoing) }\end{array}$ \\
\hline 3.3 & $\begin{array}{l}\text { Medium } \\
\text { term }\end{array}$ & $\begin{array}{l}\text { Cascading of the new Green } \\
\text { ICT strategy through the } \\
\text { organisation (1). }\end{array}$ & $\begin{array}{l}\text { May } 2019 \\
\text { (Ongoing) }\end{array}$ \\
\hline 3.4 & Long term & $\begin{array}{l}\text { Continued reinforcement of } \\
\text { Green ICT strategy and } \\
\text { raising awareness through } \\
\text { ongoing regular updates on } \\
\text { the strategy and Green ICT } \\
\text { issues }\end{array}$ & $\begin{array}{l}\text { May 2022 } \\
\text { (Ongoing) }\end{array}$ \\
\hline 4 & $\begin{array}{l}\text { Overall - } \\
\text { Long } \\
\text { term }\end{array}$ & $\begin{array}{l}\text { Evaluation and support } \\
\text { using ICT }\end{array}$ & $\begin{array}{l}\text { May 2022 } \\
\text { (Ongoing) }\end{array}$ \\
\hline 4.1 & $\begin{array}{l}\text { Medium } \\
\text { term }\end{array}$ & $\begin{array}{l}\text { Procurement / development } \\
\text { of process / equipment to be } \\
\text { used to conduct ICT audits } \\
\text { of the organisation to assess } \\
\text { energy consumption and } \\
\text { energy efficiencies of the } \\
\text { organisation }\end{array}$ & May 2019 \\
\hline 4.2 & Short term & $\begin{array}{l}\text { ICT audit of the organisation } \\
\text { in the first } 12 \text { months to } \\
\text { establish the energy } \\
\text { consumption / energy } \\
\text { efficiencies of all ICT } \\
\text { equipment. }\end{array}$ & May 2018 \\
\hline 4.3 & Medium & $\begin{array}{l}\text { Second ICT audit of the } \\
\text { organisation after } 2 \text { years to } \\
\text { establish the energy } \\
\text { consumption / energy } \\
\text { efficiencies of all ICT } \\
\text { equipment. }\end{array}$ & May 2019 \\
\hline 4.4 & Long term & $\begin{array}{l}\text { Continued ICT audits of the } \\
\text { organisation on a yearly } \\
\text { basis to assess the energy } \\
\text { consumption / efficiencies of } \\
\text { all ICT equipment in the } \\
\text { organisation }\end{array}$ & $\begin{array}{l}\text { May } 2022 \\
\text { (Ongoing) }\end{array}$ \\
\hline
\end{tabular}

\section{Conclusions}

It can be concluded from the study that the organisation currently has no formal Green ICT strategy. Despite this, the organisation does have some processes in place which are complementary to a Green ICT strategy such as compliance to Green ICT related governance and legislations (e.g. WEEE directive) and deployment of ICT as an enabler (e.g. greening other operations such as travel reduction and paper reduction). The organisation's current score of 2 out of 5 on average in the bespoke tool points to the need for a formal strategy. It is necessary for the organisation to develop a strategy for the Greening of ICT equipment and improving the overall perception of Green ICT. For this to be 
successful, the overall attitude and behaviours taken up by the organisation with regards to Green ICT must change significantly. A target has been developed for the organisation that would move the overall score up to an average of 3 out of 5. This can be achieved by following the roadmap and action plan that has been developed for this study (see Tables 3 and 4).

\subsection{Limitations of the study}

A few limitations of the study will be discussed. Conducting only an in-depth single interview has limitations as it only depicts a single perspective within the organisation. Additional interviews could be conducted to provide more data and a wider perspective of the organisation's current unwritten Green ICT strategy. This could include a more detailed study in the area of procurement within the organisation. Use of the bespoke tool provides a score for how well the current unwritten Green ICT strategy performs but this is also subjective because the score is based on the opinion of representative for the organisation. To make these scores more reliable, several representatives from diverse backgrounds could be asked to score the organisation and an average value could then be taken.

\subsection{Next steps}

After the development of the initial action plan shown in Table 3, the representative from the organisation is requested to provide feedback on the action plan. The given feedback is fed into a revised action plan (see Table 4) which highlights the next stages in the process to enable the organisation to move forward.

\subsection{Feedback on the action plan}

To reiterate, the representative from the organisation has provided feedback on the action plan which is fed into the revised action plan. Firstly, to promote the strategy, it must be presented in a more positive way that encourages people to change as reflected in the feedback comments (FC1).

"A successfully strategy has to ultimately be attractive, drive change and encourage people on the journey. A green strategy must reduce or remove inefficient and non-green choices from the portfolio; but crucially whilst still offering attractive options and not putting undue burden onto the enterprise. People are inherently resistant to change, so they need to be provided a 'better alternative'." (FC1)

Therefore, in future, a business case for the promotion of the Green ICT strategy and action plan must be written and presented to the business management. However, focus must be on ways the organisation can save money (i.e. economic benefits) and this is aligned to the highlights of three integrated benefits (environment, economic and society) in Smarter2030.

The representative agrees with the action plan viewing from both Green ICT and Greening by ICT perspectives for the organisation but once again, emphasises the need to save money to promote this to the rest of the business team (see FC2).

"It is indeed relevant to consider green \& greening ICT. In the long term, greening, such promoting energy efficiencies will save money." (FC2)

The representative mentions the use of Cloud technology as an influence in the strategy piece as this can move Scopes 1 and 2 to Scope 3 greenhouse gas emissions. This is because cloud providers prioritises green issues (see FC3). A look at migration to use of Cloud for data storage must therefore be included in the Green ICT strategy.

"Cloud (and you don't mention this) is almost the silver-bullet when it comes to the enterprise delivering on a green strategy. It moves a huge energy demand away from the enterprise, directly, and becomes the issue of the supplier/vendor. The major cloud providers can deliver on huge economies of scale, they make it their business to deliver on the green issue." (FC3)

Feasibility of the strategy is considered by the representative of the organisation. Suggestions to amend the action plan in order to consider 'compliant systems' that fit the green model for purchase rather than a complete overhaul (see FC4). Suggestions are given that there should not be a fixed time frame for this activity, but systems should be replaced as and when they are out of use to help with the business case for the organisation are to be included in the revised action plan (FC4).

"Instead, I feel you would be better placed to determine a catalogue of 'compliant' systems that fit the green model and these become the systems to be purchased. As and when systems are depreciated they are then replaced with the new models importantly investment driven by new projects is chosen from this catalogue; so by natural attrition the environment becomes green." (FC4)

Finally, the compliance with FSA standards for disaster recovery systems is considered by the representative. It is arguable that duplicated systems for preservation purposes are detrimental to energy efficiency. A risk assessment should therefore be completed for not having an immediate recovery plan for a service. It is recommended to have regular back up rather than a full duplicate. This however, is said to be hard to convince the organisation (see FC5). Consideration for this must be added to the revised action plan.

"A practice to adopt could be to understand the risks of not having an immediate recovery for a service, what are the impacts to the business? If 
they're minimal/marginal, then it's entirely possibly only a regular backup of the service is taken rather than maintaining a full duplicate." (FC5)

\subsection{Revised Action Plan}

Changes to the action plan based on the feedback are underlined (see Table 4).

\subsection{Implementation}

The next steps of this process would be implementation of the revised action plan for the organisation. This would involve converting the theoretical analysis conducted in this study into a real functioning Green ICT strategy for the organisation. Some of the issues with the implementation of the action plan may be: push back from key stakeholders; issues with feasibility in terms of cost and time frames; ensuring all parts of the action plan are conducted correctly and comprehensively.

\subsection{Evaluation}

The evaluation phase will involve regular ICT audits of the organisation at specific milestones of the roadmap and action plan to determine the carbon footprint of the organisation. These will be quantified metrics to measure whether the organisation is progressing after the implementation of the new Green ICT strategy. The evaluation stage will provide a means of evaluating if the organisation has reached its overall target. The evaluation stage will also prevent the Green ICT strategy study from being a singular linear offering. It will allow for adaptation of the Green ICT strategy as the organisation's position and external factors outside the organisation such as climate change, progress with time.

Table 4. Revised Roadmap and Action Plan for the Organisation

\begin{tabular}{|c|c|c|c|}
\hline \multicolumn{4}{|c|}{ Revised Roadmap \& Action plan for the organisation } \\
\hline $\begin{array}{l}\text { Objective } \\
\text { No. }\end{array}$ & $\begin{array}{l}\text { Objective } \\
\text { type }\end{array}$ & $\begin{array}{l}\text { Objective } \\
\text { Description }\end{array}$ & $\begin{array}{l}\text { Completion } \\
\text { Date }\end{array}$ \\
\hline 1 & $\begin{array}{l}\text { Overall - } \\
\text { Short } \\
\text { term }\end{array}$ & $\begin{array}{l}\text { Develop a Green } \\
\text { ICT Strategy for } \\
\text { the organisation }\end{array}$ & $\begin{array}{l}\text { October } \\
\underline{2018}\end{array}$ \\
\hline 1.1 & Quick Win & $\begin{array}{l}\text { Development of } \\
\text { framework of an } \\
\text { overall Green ICT } \\
\text { strategy for the } \\
\text { organisation } \\
\text { taking into } \\
\text { consideration } \\
\text { current successes } \\
\text { and areas for } \\
\text { improvement } \\
\text { within the } \\
\text { organisation with }\end{array}$ & August 2017 \\
\hline
\end{tabular}

\begin{tabular}{|c|c|c|c|}
\hline & & $\begin{array}{l}\text { regards to Green } \\
\text { ICT strategy. This } \\
\text { would include } \\
\text { alignment of } \\
\text { current processes } \\
\text { that are } \\
\text { considered } \\
\text { "Green" but are } \\
\text { carried out for } \\
\text { separate motives } \\
\text { into the Green } \\
\text { ICT strategy }\end{array}$ & \\
\hline 1.2 & Short term & $\begin{array}{l}\text { Green ICT } \\
\text { strategy } \\
\text { improvements for } \\
\text { the procurement } \\
\text { of ICT equipment }\end{array}$ & $\begin{array}{l}\text { October } \\
2017\end{array}$ \\
\hline 1.3 & Short term & $\begin{array}{l}\text { Green ICT } \\
\text { strategy } \\
\text { improvements for } \\
\text { the system } \\
\text { architecture of the } \\
\text { organisation }\end{array}$ & $\begin{array}{l}\text { October } \\
2017\end{array}$ \\
\hline 1.4 & Short term & $\begin{array}{l}\text { Green ICT } \\
\text { strategy } \\
\text { improvements for } \\
\text { the interactions } \\
\text { with suppliers and } \\
\text { outside } \\
\text { stakeholders for } \\
\text { the organisation }\end{array}$ & $\begin{array}{l}\text { October } \\
2017\end{array}$ \\
\hline$\underline{1.5}$ & Short term & $\begin{array}{l}\text { Considerations } \\
\text { for migration to } \\
\text { Cloud technology } \\
\text { within the Green } \\
\text { ICT strategy to } \\
\text { ICave on energy } \\
\text { demand }\end{array}$ & $\begin{array}{l}\text { October } \\
\underline{2017}\end{array}$ \\
\hline 1.6 & Short term & $\begin{array}{l}\text { Risk assessment } \\
\text { for replacement of } \\
\text { full duplicate } \\
\text { systems } \\
\text { (compliant with } \\
\text { FSA standards) to } \\
\text { regular back ups }\end{array}$ & $\begin{array}{l}\text { October } \\
\underline{2017}\end{array}$ \\
\hline 1.7 & Short term & \begin{tabular}{l}
\multicolumn{3}{l}{ Written business } \\
case on the \\
economic savings \\
of the Green ICT \\
strategy r to \\
advertise to the \\
wider \\
Organisation
\end{tabular} & May 2018 \\
\hline 1.8 & Short term & $\begin{array}{l}\text { Roll out of full } \\
\text { new Green ICT } \\
\text { strategy for the } \\
\text { organisation }\end{array}$ & $\begin{array}{l}\text { October } \\
\underline{2018}\end{array}$ \\
\hline 1.9 & Short term & $\begin{array}{lr}\text { Integration } & \text { of } \\
\text { Green } & \text { ICT } \\
\text { strategy within } \\
\text { overall } \\
\text { strategy for the } \\
\text { organisation } \\
\end{array}$ & May 2018 \\
\hline 2 & $\begin{array}{l}\text { Overall } \\
\text { Long } \\
\text { term }\end{array}$ & $\begin{array}{l}\text { Improvements to } \\
\text { energy } \\
\text { efficiencies of } \\
\text { ICT equipment }\end{array}$ & $\begin{array}{l}\text { August } \\
2020\end{array}$ \\
\hline 2.1 & Short term & $\begin{array}{l}\text { Establishment of } \\
\text { green compliant } \\
\text { ICT inventories } \\
\text { for the } \\
\text { organisation's } \\
\text { equipment }\end{array}$ & May 2018 \\
\hline
\end{tabular}




\begin{tabular}{|c|c|c|c|}
\hline & & $\begin{array}{l}\text { including: End } \\
\text { user equipment, } \\
\text { network } \\
\text { equipment, } \\
\text { housing } \\
\text { equipment, } \\
\text { storage equipment } \\
\text { and software. }\end{array}$ & \\
\hline 2.2 & $\begin{array}{l}\text { Medium } \\
\text { term }\end{array}$ & $\begin{array}{lr}\begin{array}{l}\text { Procurement } \\
\text { required go } \\
\text { compliant new }\end{array} \\
\text { ICT equipment } \\
\text { for } \\
\text { fimprovement of } \\
\text { energy } \\
\text { efficiencies based } \\
\text { on the inventory } \\
\text { assessment } 2.1 . \\
\text { Use of new } \\
\text { strategy for } \\
\text { procurement in } \\
\begin{array}{lr}1.1 \text { during this } \\
\text { process. }\end{array}\end{array}$ & $\begin{array}{l}\text { As and } \\
\text { when } \\
\text { necessary } \\
\text { (old } \\
\text { equipment } \\
\text { depreciates) }\end{array}$ \\
\hline 2.3 & Long term & $\begin{array}{l}\text { Roll out of } \\
\text { assessed Green } \\
\text { ICT equipment } \\
\text { that has been } \\
\text { procured in } 2.2 \text {. }\end{array}$ & $\begin{array}{l}\text { As and } \\
\text { when } \\
\underline{\text { available }}\end{array}$ \\
\hline 2.4 & Long term & $\begin{array}{l}\text { Disposal of old } \\
\text { ICT equipment } \\
\text { and e-waste } \\
\text { because of the roll } \\
\text { out } 2.3 \text {. Disposal } \\
\text { in compliance } \\
\text { with the new } \\
\begin{array}{l}\text { Green } \\
\text { strategy 1. ICT }\end{array}\end{array}$ & August 2020 \\
\hline 3 & $\begin{array}{l}\text { Overall - } \\
\text { Long } \\
\text { term }\end{array}$ & $\begin{array}{l}\text { Improvement to } \\
\text { overall } \\
\text { awareness and } \\
\text { behaviours of } \\
\text { staff in the } \\
\text { organisation } \\
\end{array}$ & $\begin{array}{l}\text { May } 2022 \\
\text { (Ongoing) }\end{array}$ \\
\hline 3.1 & Quick Win & $\begin{array}{l}\text { Presentation on } \\
\text { the key benefits } \\
\text { of a Green ICT } \\
\text { strategy and the } \\
\text { findings of this } \\
\text { study to raise } \\
\text { awareness of key } \\
\text { stakeholders and } \\
\text { leaders within the } \\
\text { organisation. }\end{array}$ & August 2017 \\
\hline 3.2 & $\begin{array}{l}\text { Short term } \\
\text { (Ongoing) }\end{array}$ & $\begin{array}{l}\text { Awareness } \\
\text { campaign on } \\
\text { Green ICT } \\
\text { strategy and the } \\
\text { effects of ICT on } \\
\text { the environment } \\
\text { within the } \\
\text { organisation. } \\
\text { Ensure campaign } \\
\text { is maintained. }\end{array}$ & $\begin{array}{l}\text { May } 2018 \\
\text { (Ongoing) }\end{array}$ \\
\hline 3.3 & $\begin{array}{l}\text { Medium } \\
\text { term }\end{array}$ & $\begin{array}{l}\text { Cascading of the } \\
\text { new Green ICT } \\
\text { strategy through } \\
\text { the organisation } \\
\text { (1). }\end{array}$ & $\begin{array}{l}\text { May } 2019 \\
\text { (Ongoing) }\end{array}$ \\
\hline 3.4 & Long term & $\begin{array}{l}l \text { Continued } \\
\text { reinforcement of } \\
\text { Green ICT } \\
\text { strategy and } \\
\text { raising awareness }\end{array}$ & $\begin{array}{l}\text { May 2022 } \\
\text { (Ongoing) }\end{array}$ \\
\hline
\end{tabular}

\begin{tabular}{|c|c|c|c|}
\hline & & $\begin{array}{l}\text { through ongoing } \\
\text { regular updates on } \\
\text { the strategy and } \\
\text { Green ICT issues }\end{array}$ & \\
\hline 4 & $\begin{array}{l}\text { Overall - } \\
\text { Long } \\
\text { term }\end{array}$ & $\begin{array}{l}\text { Evaluation and } \\
\text { support using } \\
\text { ICT }\end{array}$ & $\begin{array}{l}\text { May 2022 } \\
\text { (Ongoing) }\end{array}$ \\
\hline 4.1 & $\begin{array}{l}\text { Medium } \\
\text { term }\end{array}$ & $\begin{array}{l}\text { Procurement } \\
\text { development of } \\
\text { process } \\
\text { equipment to be } \\
\text { used to conduct } \\
\text { ICT audits of the } \\
\text { organisation to } \\
\text { assess energy } \\
\text { consumption and } \\
\text { energy } \\
\text { efficiencies of the } \\
\text { organisation }\end{array}$ & May 2019 \\
\hline 4.2 & Short term & $\begin{array}{l}\text { ICT audit of the } \\
\text { organisation in } \\
\text { the first } 12 \\
\text { months to } \\
\text { establish the } \\
\text { energy } \\
\text { consumption } \\
\text { energy } \\
\text { efficiencies of all } \\
\text { ICT equipment. }\end{array}$ & May 2018 \\
\hline 4.3 & Medium & $\begin{array}{l}\text { Second ICT audit } \\
\text { of the } \\
\text { organisation after } \\
2 \text { years to } \\
\text { establish the } \\
\text { energy } \\
\text { consumption / } \\
\text { energy } \\
\text { efficiencies of all } \\
\text { ICT equipment. }\end{array}$ & May 2019 \\
\hline 4.4 & Long term & $\begin{array}{l}\text { Continued ICT } \\
\text { audits of the } \\
\text { organisation on a } \\
\text { yearly basis to } \\
\text { assess the energy } \\
\text { consumption } \\
\text { efficiencies of all } \\
\text { ICT equipment in } \\
\text { the organisation }\end{array}$ & $\begin{array}{l}\text { May } 2022 \\
\text { (Ongoing) }\end{array}$ \\
\hline
\end{tabular}

\section{References}

[1] Bazarhanova, A., Kor, A. L., and Pattinson, C. (2016). A belief rule-based environmental responsibility assessment for small and medium-sized enterprise, IEEE Future Technologies Conference (FTC), 6-7 Dec, 2016, San Francisco, USA, DOI: 10.1109/FTC.2016.7821673.

[2] BBC News, 2017. How has the economy fared since Brexit? url: www.bbc.co.uk/news/business-36956418, accessed date: 03/03/2017.

[3] BCS, The Chartered Institute for IT. (2012). Green IT: Managing your Carbon Footprint, Publisher: British Informatics Society Ltd.

[4] Business Insider UK, 2016. Technology is disrupting the financial services industry - here's how, url: http://uk.businessinsider.com/technology-is-changing-thefinancial-services-industry-2016-1, accessed date: 17/11/2016. 
[5] Bittencourt Dolci, D., Et. Al. (2015). Implementation Of Green It In Organizations: A Structurational View, Rev. adm. empres. vol.55 no.5 São Paulo Sept./Oct. 2015, http://dx.doi.org/10.1590/S0034-759020150502

[6] Chron, 2017. Why Business Should Go Green? Url: http://smallbusiness.chron.com/businesses-should-green766.html, accessed date: 03/03/2017.

[7] Ellen MacArthur Foundation, 2015. Circular Economy Overview, url: www.ellenmacarthurfoundation.org/ circular-economy/overview/concept, accessed date: 23/03/2017.

[8] Hankel, A., and Lago, P. (2016). How Organisations Can Assess And Improve Their Green ICT Activities In A Standard And Efficient Way, ITU Kaleidoscope Academic Conference, url: http://ieeexplore.ieee.org/stamp/ stamp.jsp?arnumber=7805710, accessed date: 02/03/2018.

[9] GeSI, accenturestrategy, UNFCCC (2015). SMARTer2030 - ICT Solutions for 21st Century Challenges. Brussels, url: http://smarter2030.gesi.org/, accessed date: 02/03/2018.

[10] HM Government (2011). Greening Government: ICT strategy, London: HM Government, url: https://www.gov.uk/government/publications/greeninggovernment-ict-strategy, accessed date: 02/03/2018.

[11] Khan, R U, Khan, S, U, Kham, R, A and Ali, S (2015). Motivators in Green IT - outsoursing from Vendor's Perspective: A Systematic Literature Review, Proceedings of the Pakistan Academy of Sciences, Vol. 52(4), pp.345-360.

[12] Pattinson, C., and Kor, A. L. (nd). Green Sustainable Data Centres: Chapter 1 - Introduction to Green IT, url: https://www.ou.nl/documents/380238/382808/GSDC_01_I ntroduction_to_Green_IT.pdf/dc8ee4b1-fe22-e74f-06e625359ec125b9, accessed date: 02/03/2018.

[13] Reimsbach-Kounatze, C. (2009). Towards Green ICT Strategies: Assessing Policies and Programmes on ICT and the Environment, OECD Digital Economy Papers, No. 155, OECD Publishing, Paris.http://dx.doi.org/10.1787/ 222431651031

[14] Shaw, J., Kor, A. L., and Pattinson, C. (2016). An Evaluation of the Impact of Remote Collaboration Tools on Corporate Sustainability, IEEE 14th Intl Conference on Dependable, Autonomic and Secure Computing, Pervasive Intelligence and Computing, Big Data Intelligence and Computing and Cyber Science and Technology, Congress (DASC/PiCom/DataCom/CyberSciTech), 8-12 Aug. 2016, Auckland, New Zealand, 10.1109/DASC-PIComDataCom-CyberSciTec.2016.63.

[15] SURF, (2014). SURF Green ICT Maturity Model, url: https://www.surf.nl/en/knowledge-base/2014/surf-greenict-maturity-model.html, accessed date: 02/03/2018.

[16] The Royal Borough of Kensington and Chelsea. (2008). Green ICT Strategy Efficient, Sustainable, Responsible, London: The Royal Borough of Kensington and Chelsea.
[17] UK Government / AEA. (2010). Adapting the ICT Sector to the Impacts of Climate Change by UK Government, Didcot, Oxfordshire: Crown, url: https://www.gov.uk/government/uploads/system/uploads/a ttachment_data/file/183486/infrastructure-aea-full.pdf, accessed date: 02/03/2018.

[18] United States Environmental Protection Agency (EPA), 2017. Learn about Environmental Management Systems, url: https://www.epa.gov/ems/learn-aboutenvironmental-management-systems\#what-is-an-EMS, accessed date: 0/03/2017.

[19] Zoological Society of London, Global Footprint Network, Water Footprint Network, WWF. (2014). Living Planet Report 2014, url:https://www.wwf.or.jp/activities/ data/WWF_LPR_2014.pdf, accessed date: 02/03/2018. 